\title{
Climate impact research: beyond patchwork
}

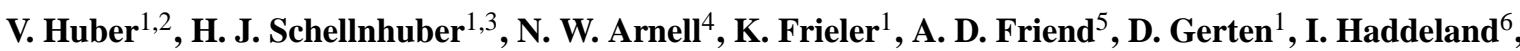 \\ P. Kabat ${ }^{7}$, H. Lotze-Campen ${ }^{1}$, W. Lucht ${ }^{1,8}$, M. Parry ${ }^{9}$, F. Piontek ${ }^{1}$, C. Rosenzweig ${ }^{10}$, J. Schewe ${ }^{1}$, and \\ L. Warszawski ${ }^{1}$ \\ ${ }^{1}$ Potsdam Institute for Climate Impact Research (PIK), Potsdam, Germany \\ ${ }^{2}$ European Commission's Joint Research Centre, Institute for Prospective Technological Studies (IPTS), \\ Seville, Spain \\ ${ }^{3}$ Santa Fe Institute (SFI), New Mexico, USA \\ ${ }^{4}$ Walker Institute for Climate System Research, University of Reading, Reading, UK \\ ${ }^{5}$ Department of Geography, University of Cambridge, Cambridge, UK \\ ${ }^{6}$ Norwegian Water Resources and Energy Directorate (NVE), Oslo, Norway \\ ${ }^{7}$ International Institute of Applied Systems Analysis, Laxenburg, Austria \\ ${ }^{8}$ Department of Geography, Humboldt-Universität zu Berlin, Berlin, Germany \\ ${ }^{9}$ Grantham Institute for Climate Change Research, Imperial College London, London, UK \\ ${ }^{10}$ NASA Goddard Institute for Space Studies, New York, USA \\ Correspondence to: V. Huber (huber@ pik-potsdam.de)
}

Received: 14 May 2014 - Published in Earth Syst. Dynam. Discuss.: 17 June 2014

Revised: 14 September 2014 - Accepted: 30 September 2014 - Published: 13 November 2014

\begin{abstract}
Despite significant progress in climate impact research, the narratives that science can presently piece together of a $2,3,4$, or $5^{\circ} \mathrm{C}$ warmer world remain fragmentary. Here we briefly review past undertakings to characterise comprehensively and quantify climate impacts based on multi-model approaches. We then report on the Inter-Sectoral Impact Model Intercomparison Project (ISI-MIP), a community-driven effort to compare impact models across sectors and scales systematically, and to quantify the uncertainties along the chain from greenhouse gas emissions and climate input data to the modelling of climate impacts themselves. We show how ISI-MIP and similar efforts can substantially advance the science relevant to impacts, adaptation and vulnerability, and we outline the steps that need to be taken in order to make the most of the available modelling tools. We discuss pertinent limitations of these methods and how they could be tackled. We argue that it is time to consolidate the current patchwork of impact knowledge through integrated cross-sectoral assessments, and that the climate impact community is now in a favourable position to do so.
\end{abstract}

\section{Introduction}

Climate-change research has come a long way towards determining the magnitude of required emissions reductions given a politically chosen global warming limit (e.g. Rogelj et al., 2011), as well as the means and costs of achieving those reductions (e.g. Clarke et al., 2009; Edenhofer et al., 2010). However, despite a wealth of knowledge about climate change impacts, the scientific basis for describing the consequences of different global warming levels remains "seriously incomplete" (Rosenzweig and Wilbanks, 2010; Impacts World Conference, 2013).
The current state of the art would notably benefit from comprehensive quantitative assessments of aggregate global climate change impacts (Schellnhuber et al., 2014). Addressing this knowledge gap would greatly strengthen the scientific underpinning of mitigation decisions, and is all the more urgent in light of a potential review of the internationally agreed upon target of stabilising global mean temperature (GMT) rise below $2^{\circ} \mathrm{C}$ (UNFCCC, 2010). Climate research is also challenged to provide more robust and implementable information on climate change impacts - in particular at local and regional scales - for making science-based adaptation choices in a warmer world (Kerr, 2011). 
Progress is particularly needed in two research areas that have been largely neglected in the past - largely because of the complexity of the challenges involved.

Firstly, climate impact research should strive for stronger integration of different sectors (such as agriculture, water resources, forestry, infrastructure, and industrial production) and spatial scales (local, regional, global). Assessing the vulnerability of human and natural systems to climate change should account for the interactive effects of simultaneous and/or sequential impacts, which due to feedbacks and nonlinearities cannot be deduced from sector-specific studies alone (Smith et al., 2001). So far, cascading impacts across sectors - such as the effects of climate-induced yield loss on malnutrition, the effects of ecosystem change on malaria distribution, or the propagation of local damages along the global supply network - are poorly understood (Warren, 2011). Better understanding of these multi-sectoral interactions and the involved trade-offs is especially important in the light of adaptation planning, as coping resources (such as land area, public and private funds, and political will) are often limited.

Improved integrative analysis across different spatial scales would help to bridge the gap between global impact assessments, currently not apt for local adaptation planning, and local or regional approaches, which so far leave many parts of the world "unexplored". Using data from local and regional models, for example, provides a large potential for the improvement and better parameterisation of global models (Challinor et al., 2014a), which could eventually become appropriate tools for devising global as well as local adaptation measures.

Secondly, more emphasis could be put on the systematic and rigorously quantitative assessment of uncertainties, which is indispensable if scientific findings are effectively to support the climate-policy process as it moves towards quantitative risk assessment (Schneider and Mastrandrea, 2005; Kunreuther et al., 2013). Hence, error ranges stemming from climatic and socio-economic projections should be considered alongside uncertainty in the current understanding of impacts per se.

Statistical (meta-)analyses and expert judgments (e.g. Challinor et al., 2014b; Smith et al., 2009), building on a wealth of specific case studies and empirical data, are important elements of the necessary toolkit for addressing these research gaps. Here our focus is on modelling approaches, which are particularly well suited to integrating existing knowledge and quantitatively assessing uncertainties. It is worth noting that the discussion about economic modelling frameworks (i.e. integrated assessment models), including the controversial debate on the representation of climate impacts in these models (e.g. Pindyck, 2013; Stern, 2013), is beyond the scope of this study, despite their significance for the aggregation of climate impacts and their important contribution to uncertainty assessments.

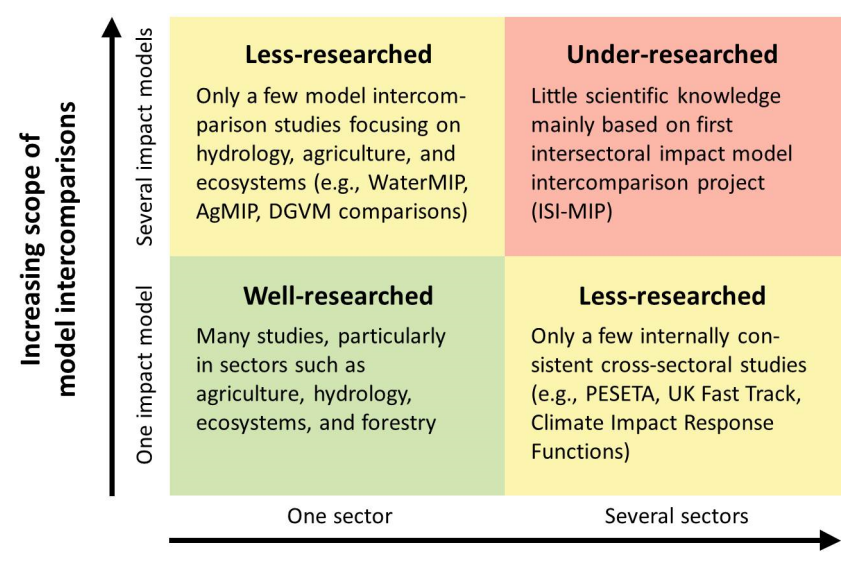

Increasing sectoral integration

Figure 1. State of global climate impact modelling in terms of sectoral integration and existing model intercomparison projects. Most studies to date have been based on one single-sector impact model, limited to exploring the uncertainty in climate projections by using input from different climate models (lower left quadrant). Only a few studies have included several sectors within one common scenario setup, using one impact model per sector (lower right quadrant). Likewise, only a few studies have compared impact models within one sector allowing for the analysis of structural uncertainties (upper left quadrant). The recently initiated Inter-Sectoral Impact Model Intercomparison Project (ISI-MIP) considers impact model ensembles in several sectors simultaneously (upper right quadrant).

To begin with, we describe efforts to extend firstgeneration impact modelling schemes, based on just one (biophysical) impact model for one sector, to include (i) several sectors and (ii) an ensemble of impact models (Fig. 1). We then turn to recent studies that combine a coherent analysis of climate impacts across sectors with a comprehensive, multi-model assessment of uncertainties. Many of these studies have come out of the recently initiated Inter-Sectoral Impact Model Intercomparison Project (ISI-MIP). In the main part of the paper, we discuss some of the most important results from ISI-MIP and similar projects in light of the two major knowledge gaps related to the sectoral integration and characterisation of uncertainties. Despite well-acknowledged shortcomings of existing model intercomparison efforts, we argue that the climate impacts, adaptation and vulnerability (IAV) community should continue along the multi-sector, multi-model road it has now taken. 


\section{Integrative, model-based assessments of climate impacts - established approaches}

\subsection{Several sectors, one model}

Significant progress has been made recently in the crosssectoral synthesis of climate impact knowledge based on either single, internally consistent multi-sectoral models or suites of independent sectoral models. These two approaches complement each other. The former class of integrated models obviously allows for the direct simulation of crosssectoral feedbacks and interactions, but often suffers from a less detailed representation of processes due to computational limitations. Also, despite some progress in constructing more comprehensive integrated modelling platforms (Howells et al., 2013), so far, such studies have focused on closely related sectors only, such as water and ecosystems (e.g. Gerten et al., 2013), or ecosystems and agriculture (e.g. Gervois et al., 2008). By contrast, the latter approach of combining offline simulations of different uncoupled impact models currently allows for more comprehensive impact assessments, covering a higher sectoral diversity.

Here, we mention as examples a number of projects (forming an incomplete list) that fall into the latter category. It is worthwhile noting that some of these projects comprise some element of model intercomparison (albeit not to the extent ISI-MIP does) and thus fulfil some criteria of the subsequently discussed integration approaches.

Within the PESETA project (Projection of Economic impacts of climate change in Sectors of the European Union based on bottom-up Analysis) consequences of climate change across the European continent were quantified by integrating a set of high-resolution impact projections into a single economic modelling framework (Ciscar et al., 2011). The recently concluded second phase of the project considered eight sectors: agriculture, energy, river floods, forest fires, transport infrastructure, coastal areas, tourism, and human health (Ciscar et al. 2014). Similar integrated assessments of climate impacts in the United States are underway, as part of the Climate Impact and Risk Analysis (CIRA) project (Waldhoff et al., 2014). The CIRA project employed over twenty detailed impact models with the primary goal of assessing the regional benefits of global mitigation efforts across six broad impact sectors. Early examples of multisectoral, model-based climate-change risk assessments on the global scale are the UK Fast Track project (Parry et al., 1999) and the Climate Impact Response Functions initiative (Füssel et al., 2003), but there are very few other comparable studies. More recently, the study by Arnell et al. (2013) provided projections of climate impacts in six sectors (water availability, river flooding, coastal flooding, agriculture, ecosystems, and energy demands) on the global scale, using a coherent set of climatic and socio-economic scenarios. However, the majority of these studies used only one impact model per sector, and were thus unable to address uncertain- ties beyond those arising from climatic and socio-economic input data.

\subsection{Several models, one sector}

On the other hand, impact model intercomparison efforts, which provide a basis for quantifying and classifying these uncertainties, have so far typically focused on one specific sector or region. Examples of global studies include the assessment of uncertainty in the response of the global terrestrial biosphere to increasing $\mathrm{CO}_{2}$ concentrations and rising temperatures, by comparing simulations of a suite of dynamic global vegetation models (DGVMs; Cramer et al., 2001; Sitch et al., 2008). More recently, a large number of global hydrological and land-surface models were compared in the WaterMIP initiative (Haddeland et al., 2011; Hagemann et al., 2013), building upon earlier model comparison efforts in the water sector (Dirmeyer et al., 1999; Hoff et al., 2010). An important ongoing community initiative is the Agricultural Model Intercomparison and Improvement Project (AgMIP), an ambitious multi-scale, multi-model impact assessment in the agricultural sector (Rötter et al., 2011; Rosenzweig et al., 2013). Several other research projects have combined impact model ensembles with observational records to analyse causes of past climate effects (e.g. on the carbon and water cycles) (Vetter et al., 2008; Jung et al., 2010), rather than to provide future projections. Regional examples include the comparison of modelling schemes to assess climate change consequences for the hydrological cycle in the US (Xia et al., 2012) and in the monsoon-dominated countries of western Africa (Ruti et al., 2011).

\section{The Inter-Sectoral Impact Model Intercomparison Project (ISI-MIP)}

The ISI-MIP, launched in 2012 (Schellnhuber et al., 2014), is an example of a new type of community effort situated in the otherwise largely unpopulated upper right corner of the impact integration matrix (Fig. 1). It builds upon existing sectoral model intercomparison efforts, such as the WaterMIP and AgMIP initiatives, but is designed to integrate these and other impact simulation schemes across sectors and scales. Integration pursued in ISI-MIP entails running models of different sectors and scales with a minimum level of harmonisation and common input data, rather than dynamically linking these models.

In its recently concluded fast-track phase, the ISI-MIP involved more than thirty international modelling teams and covered five sectors (agriculture, water, ecosystems, coastal infrastructure, and health) (Warszawski et al., 2014). Global impact projections were based on common bias-corrected climate input data (Hempel et al., 2013) and socio-economic indicators, using state-of-the-art climate-change and socioeconomic scenarios representative concentration pathways 


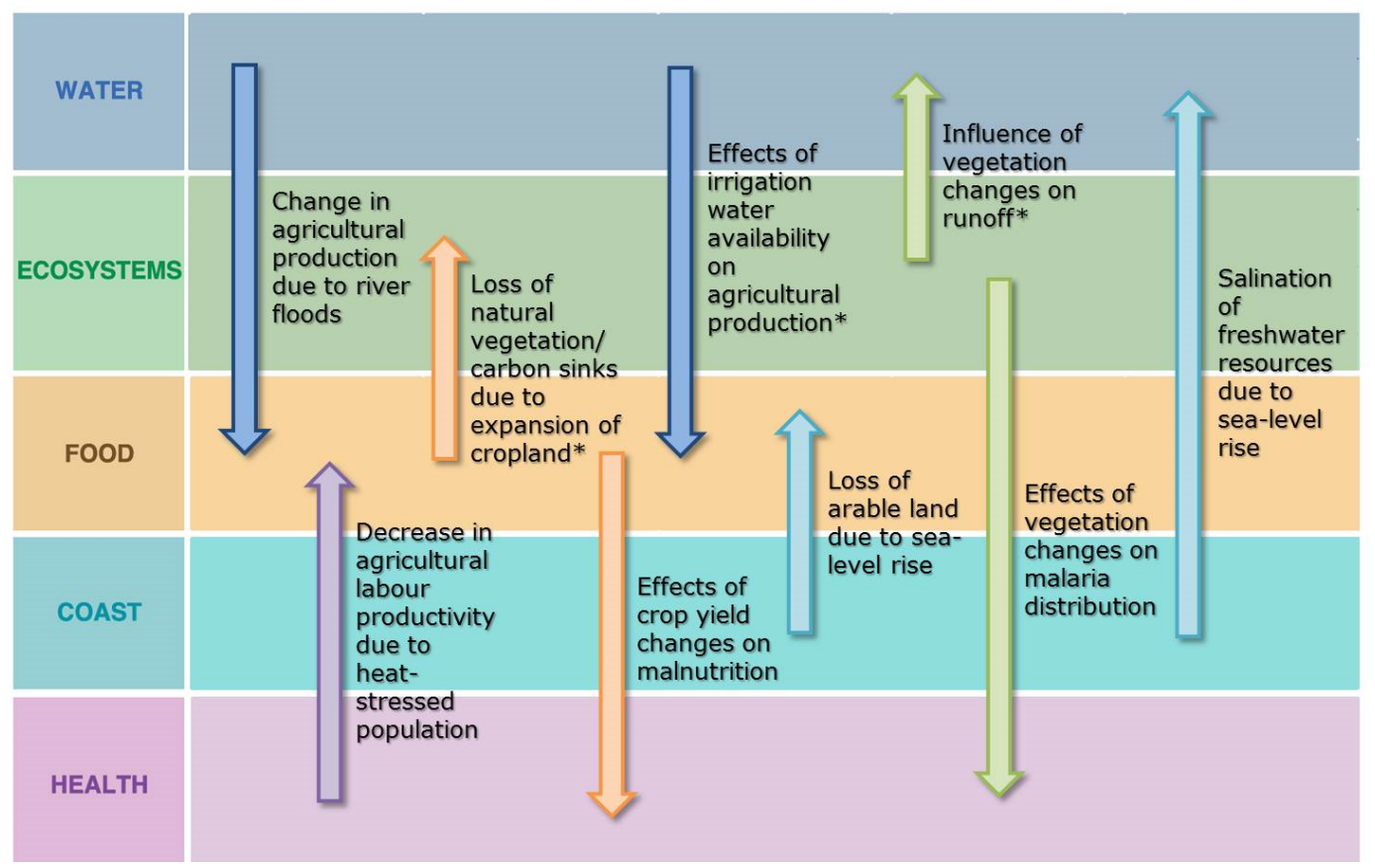

Figure 2. Climate-impact cascades across sectors. Each arrow, overlain on the standard impact table from the 4th IPCC assessment report (Parry et al., 2007), illustrates an exemplary inter-sectoral feedback. Whereas previous studies have commonly focused on individual sectors in isolation (along the horizontal dimension), integrative efforts - such as ISI-MIP and AgMIP - now also allow for the analysis of feedbacks and interactions across sectors (along the vertical dimension). *Feedbacks recently studied in the context of ISI-MIP (Davie et al., 2013; Wada et al., 2013; Elliott et al., 2014; Frieler et al., 2014).

(RCPs; Moss et al., 2010) and shared socio-economic pathways (SSPs; Van Vuuren et al., 2012).

Major results of the ISI-MIP fast track were recently discussed by Schellnhuber et al. (2014). Here we present a synopsis of important advances made by ISI-MIP and other recent multi-model efforts with regards to (i) the integration of impact projections across sectors and spatial scales, and (ii) the quantification and classification of uncertainties. We also define related research challenges, which should now be addressed by the scientific community.

\section{Cross-sectoral intercomparison of impact models - major advances and future challenges}

\subsection{Integrating impact projections across sectors and spatial scales}

Juxtaposing impact measures from different sectors in order to synthesise impacts requires a common scenario framework. Earlier approaches, such as the summaries of impacts at different levels of GMT rise presented by Hare (2006) and Warren (2006), constitute important steps forward, but were not always based on harmonised input (in particular with regard to non-climatic drivers such as population scenarios and land-use patterns). Integrative efforts that function as intersectoral exercises from the outset circumvent such inconsistencies. For example, based on ISI-MIP multi-model ensem- bles, Piontek et al. (2014) presented an analysis of coinciding biophysical impacts in four different sectors (agriculture, water, ecosystems, health) to identify regional hotspots. Their analysis included estimates of the number of people exposed to severe change in one or several sectors, measured as significant departures from the historical norm. The areas identified as hotspots in this analysis are of course contingent on the limited number of sectors considered, and the employed definitions of severe change.

An important development towards a more general map of climate change hotspots would be to move from exposure analyses to actual impact assessments that account for vulnerabilities and adaptive responses. As a first step, the results from ISI-MIP allow for the assessment of inter-sectoral interactions and adaptation trade-offs (Fig. 2), based on consistent multi-sector, multi-model data. Using output of up to 11 global hydrological models and 7 crop models, two recent studies (Elliott et al., 2014; Frieler et al., 2014) have, for example, investigated the effect of climate change on food production - directly, through climate-induced yield changes, and indirectly, through the constraint that changing availability of freshwater puts on the enhancement of irrigation. Complementing the multi-sectoral ensemble by 7 global vegetation models, Frieler et al. (2014) have additionally studied the loss of natural carbon sinks resulting from the expansion of cropland required to meet the projected food demand. The 
necessary simulation data are now available to explore further important inter-sectoral interactions and trade-offs, such as the loss of arable land to sea-level rise, or the effect of river floods on agricultural production (Fig. 2).

When integrating different sectors, it is important to include those that are socially relevant but which have largely been ignored in the past. Climate impacts on agriculture, hydrology, ecosystems and forestry have been the subject of intensive research. It is questionable whether the concept of more or less clearly distinct sectors is a good one to start with. However, the broad areas of human health, migration, transport, infrastructure (also beyond coastal areas), energy production and distribution, settlements (including megacities), and marine ecosystems, clearly require the attention of the impact research community. For some of these areas, not even one global-scale model exists yet, let alone ensembles of comparable models.

Regarding the integration across different spatial scales, it is generally agreed that process-based impact models operating on different spatial scales are yet to be systematically tested and compared (Challinor et al., 2014a). Global models often agree on large-scale patterns of change, but diverge in their projections of specific changes on the regional scale (where even the sign of the change often differs between models) (Warszawski et al., 2013; Dankers et al., 2014). Comparing global and regional models in selected areas (e.g. major river basins or critical biomes such as the Amazon or boreal forests) may contribute to constraining these large regional uncertainties. Global models may "learn" from the regional ones and help to generalise their results by extrapolations to other regions not covered by regional simulations. Driving global impact models with higher-resolution climate input (so-called hyper-resolution global modelling) is another avenue potentially to improve local and regional projections (Wood et al., 2011). Pinpointing and reducing the existing scale dependency (Boone et al., 2004) constitutes an important step towards the eventual use of global models for on-the-ground adaptation planning.

\subsection{Quantifying and classifying uncertainties}

"Perturbed physics ensembles" commonly explore parametric uncertainties associated with a single model (e.g. Challinor et al., 2009), with the major advantage that causes of model spread can often be traced back to specific parameters and processes. "Ensembles of opportunity", based on the comparison of several process-based impact models, constitute another widespread approach to deriving probabilistic assessments of climate change impacts. The challenge lies in appropriately interpreting these multi-model simulations (Sanderson and Knutti, 2012). The conventional approach, which has been adopted by the majority of ISI-MIP-related studies (e.g. Haddeland et al., 2014; Schewe et al., 2014), is to treat all model output equally - despite model interdependencies and common genealogies. This issue has been widely discussed in the global climate modelling community (Knutti, 2010), but requires more attention from climate impact modellers in light of the increasing number of multimodel assessments in this field.

If some models share more code or concepts than others, or multiple versions of one model enter the ensemble, a simple average of model outputs is necessarily biased, as these models are implicitly given greater weight (Knutti et al., 2013). Understanding model genealogy is thus important for assessing the significance of this bias, yet it has rarely been made transparent for ensembles of global impact models (GIMs); however, see Rosenzweig et al. (2014) for a genealogy of global crop models.

A complementary approach, often adopted by global climate modellers, is weighting simulation output based on model performance compared to observations. In this context, a robust definition of what constitutes a "better" or "poorer" model performance (Tebaldi and Knutti, 2007) would be required. One important question with regard to GCMs is, for example, to what extent the models' ability to represent current climate is related to their ability to represent future climates (Knutti, 2010). To our knowledge, the only example of weighting impact models based on performance so far can be found in a recent AgMIP study (Asseng et al., 2013) on the uncertainty of simulating wheat yields under climate change. Previous studies have rather relied on weighted GCM output for deriving probabilistic impact assessments (e.g. Rammig et al., 2010).

Beyond probabilistic interpretation of multi-model ensembles, integrative modelling frameworks such as ISI-MIP allow for the identification of contributions to uncertainty from different sources. A major finding emerging from these recent multi-model assessments of climate impacts is that the uncertainty stemming from GIMs is generally larger than the uncertainty stemming from GCMs (e.g. for hydrology models: Schewe et al., 2014; for crop models: Rosenzweig et al., 2014; for malaria models: Caminade et al., 2014; for vegetation models: Warszawski et al., 2013; see also Fig. 3). One could deduce from this finding that investment in impact model development and improvement - rather than further constraining climate input data - is paramount in order to reduce the overall uncertainty of climate impact projections. This conclusion would also be supported by the argument that great effort has already been put into the development of GCMs, but that there might be much to be gained with regard to the improvement of GIMs, for comparably little investment.

However, there are several important caveats to this statement. Firstly, bias correction applied to GCM output will reduce the inter-GCM variability, thereby potentially reducing the contribution of GCMs to the total uncertainty of impact simulations (Dankers et al., 2014; Wada et al., 2013). A recent study using global hydrological models concluded that the uncertainty related to statistical bias correction is of the same order of magnitude as the uncertainties related to 

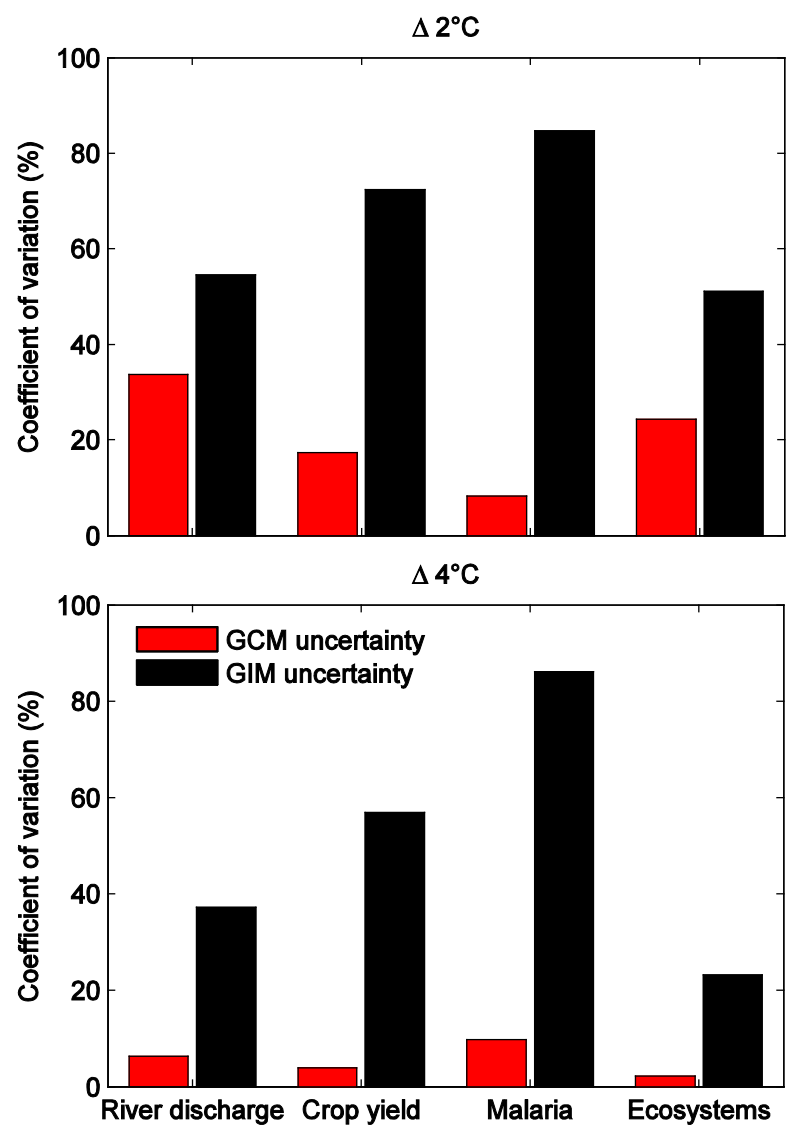

Figure 3. Uncertainty due to global climate models (GCMs) (red) and global impact models (GIMs) (black) in four different impact sectors at $2{ }^{\circ} \mathrm{C}$ (top) and $4{ }^{\circ} \mathrm{C}$ (bottom) GMT rise. Coefficients of variation were calculated based on data of model spread from $\mathrm{Pi}$ ontek et al. (2014), who compute climate impacts as the fraction of global land surface subject to "severe" changes in 30-year averages of river discharge, crop yields, ecosystem characteristics, and the length of the malaria transmission season at given GMT levels. Multi-model ensembles consist of 11 hydrological models, 7 crop models, 4 malaria models, and 7 vegetation models. Climate input data were taken from $3 \mathrm{GCMs}$.

the choice of GCM or GIM (Hagemann et al., 2011). More in-depth studies on the role of bias correction should definitely be high up on the agenda of climate impact research. (As a matter of fact, all statements about the relative contributions of GCMs and GIMs to total impact uncertainty made here would need to stand the test of using non-biascorrected GCM data.) Secondly, the proportion of uncertainty due to GIMs and GCMs is contingent on the respective ensemble sizes and characteristics (also pointed out by Prudhomme et al., 2014). ISI-MIP relied on a subset of 5 GCMs out of nearly $30 \mathrm{GCMs}$ participating in the latest phase of the Coupled Model Intercomparison Project (CMIP5) (Taylor et al., 2011), which points to the need for more comprehensive analyses in the future. Thirdly, what is true for globally aggregated metrics may not apply on the regional scale.
For example, while GIMs contribute the largest proportion to the total uncertainty in the length of the malaria transmission season across most of the globe, variations between GCMs dominate in regions where their precipitation projections diverge most strongly (Caminade et al., 2014). Fourthly, the decomposition of uncertainty may change with both time and the magnitude of GMT change (cf. Fig. 3, top and bottom). In support of this argument, Wada et al. (2013) have found that the contribution of GCMs to the overall uncertainty in simulations of global irrigation water demand is greater at higher GMT change. It follows from the third and fourth caveats that the task of constraining uncertainty may differ strongly, depending on whether the goal is to inform near-term, regional adaptation or long-term, global mitigation decisions.

Finally, exploring the reasons for inter-model differences can contribute to an improved understanding of the mechanisms that produce specific climate impacts. For example, Friend et al. (2014) found that the implementation of plant respiration and mortality processes in global vegetation models is key to explaining the different carbon source-sink dynamics simulated by these models. Taking a closer look at ensemble spreads by comparing the output of different model classes (e.g. site-based and ecosystem-type global crop models: Rosenzweig et al., 2014; hydrological models with and without dynamic vegetation: Davie et al., 2013) forms an important basis for future model development and improvement.

\section{General limitations of model intercomparison approaches}

Despite being powerful means of integration and uncertainty assessment, multi-model approaches are no panacea for the currently incomplete patchwork of impact knowledge. CMIP, which now provides global climate projections in its fifth phase (Taylor et al., 2011), is a suitable reference point to judge not only the successes of, but also the risks involved in, tightly integrated approaches. Ensemble convergence often results from consensus on metrics and observational data sets rather than a converging understanding of processes. Knutti (2010) suggested that there may even be an "element of social anchoring": without any deliberate adjustment of models, participating groups tend to produce results that fall in the middle of the ensemble instead of representing an outlier. It is also worth noting that uncertainty in global climate projections (e.g. GMT, seasonal and spatial patterns of temperature and precipitation change) has not been considerably reduced between CMIP3 and CMIP5 (Knutti and Sedláček, 2013), despite continuing efforts into model development and improvement.

Another potential shortcoming may arise in the communication of results to policy makers. Individual models and small ensembles consisting of only a few models can of course provide policy-relevant information. However, the 
general risk involved is that critical information on the assumptions and characteristics of single models or model ensembles is not conveyed to policy makers, making results appear more general than they actually are. One example stems from the intercomparison of integrated assessment models led by the Energy Modeling Forum (EMF), which provided estimates of the economic costs of stringent mitigation policies for the fourth IPCC assessment report. Since not all models were able to run the lowest emission reduction scenario, it was later controversially discussed whether these estimates were biased due to the selection of specific model types in the considered EMF sub-ensemble (Tavoni and Tol, 2010; Knopf et al., 2011).

\section{Conclusions}

Keeping these caveats in mind, systematic and integrative model intercomparisons in climate impact research (such as initiated by ISI-MIP, AgMIP, and similar projects) nonetheless constitute a major step forward. As demonstrated here, they are already on the road to delivering significant progress towards an improved quantitative and consistent view of a world exposed to a $2,3,4$, or $5^{\circ} \mathrm{C}$ higher GMT.

In the short term, improved understanding of climate impacts across sectors and scales will support policy makers in their review of the $2{ }^{\circ} \mathrm{C}$ temperature target (UNFCCC, 2010). Inter-sectoral considerations can make a difference in policy making, as recently demonstrated, for example, by an integrated analysis of climate change, land use, energy and water strategies with regard to the establishment of a local biofuel industry in Mauritius (Howells et al., 2013).

In the longer term, establishing a community-driven process that compares and evaluates impact models regularly according to well-defined procedures will bring climate impact research onto an equal footing with the corresponding climatological and climate-economic sciences. In the latter fields, intercomparisons of GCMs and earth system models (such as in CMIP), and of integrated assessment models (as through the Integrated Assessment Modelling Consortium, IAMC), respectively, have evolved into community benchmarks. As such, they advance the science and contribute significantly to increasing transparency and accessibility of modelling results. A comprehensive, publicly accessible archive of climate-change impact simulations, similar to that provided by the CMIP archive, would synthesise the state of the art in impact modelling and would guide the scientific community in further addressing crucial model gaps and inconsistencies among models. The ISI-MIP data archive, which is now openly available, provides a good starting point, but would require a much broader involvement of the IAV research community to live up to its full potential.
Acknowledgements. This work has been conducted under the framework of the Inter-Sectoral Impact Model Intercomparison Project (ISI-MIP) Fast Track, funded by the German Federal Ministry of Education and Research (reference number 01LS1201A).

Edited by: D. Lapola

\section{References}

Arnell, N. W., Lowe, J. A., Brown, S., Gosling, S. N., Gottschalk, P., Hinkel, J., Lloyd-Hughes, B., Nicholls, R. J., Osborn, T. J., Osborne, T. M., Rose, G. A., Smith, P., and Warren, R. F.: A global assessment of the effects of climate policy on the impacts of climate change, Nat. Clim. Change, 3, 512-519, 2013.

Asseng, S., Ewert, F., Rosenzweig, C., Jones, J. W., Hatfield, J. L., Ruane, A. C., Boote, K. J., Thorburn, P. J., Rotter, R. P., Cammarano, D., Brisson, N., Basso, B., Martre, P., Aggarwal, P. K., Angulo, C., Bertuzzi, P., Biernath, C., Challinor, A. J., Doltra, J., Gayler, S., Goldberg, R., Grant, R., Heng, L., Hooker, J., Hunt, L. A., Ingwersen, J., Izaurralde, R. C., Kersebaum, K. C., Mueller, C., Kumar, S. N., Nendel, C., O'Leary, G., Olesen, J. E., Osborne, T. M., Palosuo, T., Priesack, E., Ripoche, D., Semenov, M. A., Shcherbak, I., Steduto, P., Stoeckle, C., Stratonovitch, P., Streck, T., Supit, I., Tao, F., Travasso, M., Waha, K., Wallach, D., White, J. W., Williams, J. R., and Wolf, J.: Uncertainty in simulating wheat yields under climate change, Nat. Clim. Change, 3, 827-832, 2013.

Boone, A., Habets, F., Noilhan, J., Clark, D., Dirmeyer, P., Fox, S., Gusev, Y., Haddeland, I., Koster, R., Lohmann, D., Mahanama, S., Mitchell, K., Nasonova, O., Niu, G.-Y., Pitman, A., Polcher, J., Shmakin, A. B., Tanaka, K., van den Hurk, B., Vérant, S., Verseghy, D., Viterbo, P., and Yang, Z.-L.: The RhoneAggregation Land Surface Scheme Intercomparison Project: An Overview, J. Climate, 17, 187-208, 2004.

Caminade, C., Kovats, S., Rocklov, J., Tompkins, A. M., Morse, A. P., Colón-González, F. J., Stenlund, H., Martens, P., and Lloyd, S. J.: Impact of climate change on global malaria distribution, Proc. Natl. Acad. Sci. USA, 111, 3286-3291, 2014.

Challinor, A. J., Wheeler, T., Hemming, D., and Upadhyaya, H. D.: Ensemble yield simulations: crop and climate uncertainties, sensitivity to temperature and genotypic adaptation to climate change, Clim. Res., 38, 117-127, 2009.

Challinor, A., Martre, P., Asseng, S., Thornton, P., and Ewert, F.: Making the most of climate impacts ensembles, Nat. Clim. Change 4, 77-80, 2014a.

Challinor, A. J.,Watson, J., Lobell, D. B., Howden, S. M., Smith, D. R., and Chhetri, N.: A meta-analysis of crop yield under climate change and adaptation, Nat. Clim. Change, 4, 287-291, $2014 \mathrm{~b}$.

Ciscar, J.-C., Iglesias, A., Feyen, L., Szabo, L., Van Regemorter, D., Amelung, B., Nicholls, R., Watkiss, P., Christensen, O. B., Dankers, R., Garrote, L., Goodess, C. M., Hunt, A., Moreno, A., Richards, J., and Soria, A.: Physical and economic consequences of climate change in Europe, Proc. Natl. Acad. Sci. USA, 108, 2678-2683, 2011.

Ciscar, J. C., Feyen, L., Soria, A., Lavalle, C., Raes, F., Perry, M., Nemry, F., Demirel, H., Rozsai, M., Dosio, A., Donatelli, M., Srivastava, A., Fumagalli, D., Niemeyer, S., Shrestha, S., Ciaian, P., Himics, M., Van Doorslaer, B., Barrios, S., Ibáñez, N., Forzieri, G., Rojas, R., Bianchi, A., Dowling, P., Camia, A., Lib- 
ertà, G., San Miguel, J., de Rigo, D., Caudullo, G., Barredo, J.I., Paci, D., Pycroft, J., Saveyn, B., Van Regemorter, D., Revesz, T., Vandyck, T., Vrontisi, Z., Baranzelli, C., Vandecasteele, I., Batista e Silva, F., and Ibarreta, D.: Climate Impacts in Europe. The JRC PESETA II Project, JRC Scientific and Policy Reports, EUR 26586EN, 2014.

Clarke, L., Böhringer, C., and Rutherford, T. F. (Eds.): International, U.S. and E.U. Climate Change Control Scenarios: Results from EMF 2, Energ. Econom., 31, S63-S306, 2009.

Cramer, W., Bondeau, A., Woodward, F. I., Prentice, I. C., Betts, R. A., Brovkin, V., Cox, P. M., Fisher, V., Foley, J. A., Friend, A. D., Kucharik, C., Lomas, M. R., Ramankutty, N., Sitch, S., Smith, B., White, A., and Young-Molling, C.: Global response of terrestrial ecosystem structure and function to $\mathrm{CO}_{2}$ and climate change: results from six dynamic global vegetation models, Global Change. Biol., 7, 357-373, 2001.

Dankers, R., Arnell, N. W., Clark, D. B., Falloon, P. D., Fekete, B. M., Gosling, S. N., Heinke, J., Kim, H., Masaki, Y., Satoh, Y., Stacke, T., Wada, Y., and Wisser, D.: First look at changes in flood hazard in the Inter-Sectoral Impact Model Intercomparison Project ensemble, Proc. Natl. Acad. Sci. USA, 111, 3257-3261, 2014.

Davie, J. C. S., Falloon, P. D., Kahana, R., Dankers, R., Betts, R., Portmann, F. T., Wisser, D., Clark, D. B., Ito, A., Masaki, Y., Nishina, K., Fekete, B., Tessler, Z., Wada, Y., Liu, X., Tang, Q., Hagemann, S., Stacke, T., Pavlick, R., Schaphoff, S., Gosling, S. N., Franssen, W., and Arnell, N.: Comparing projections of future changes in runoff from hydrological and biome models in ISI-MIP, Earth Syst. Dynam., 4, 359-374, doi:10.5194/esd-4359-2013, 2013.

Dirmeyer, P. A., Dolman, A. J., and Sato, N.: The pilot phase of the Global Soil Wetness Project, B. Am. Meteorol. Soc., 80, 851-878, 1999.

Edenhofer, O., Knopf, B., Leimbach, M., and Bauer, N. (Eds.): The economics of low stabilization: exploring its implications for mitigation costs and strategies, Special Issue, Energy J., https://www.pik-potsdam.de/research/sustainable-solutions/ flagshipspld/MitigationScenarios/adam/adam-project, 2010.

Elliott, J., Deryng, D., Müller, C., Frieler, K., Konzmann, M., Gerten, D., Glotter, M., Flörke, M., Wada, Y., Best, N., Eisner, S., Fekete, B. M., Folberth, C., Foster, I., Gosling, S. N., Haddeland, I., Khabarov, N., Ludwig, F., Masaki, Y., Olin, S., Rosenzweig, C., Ruane, A. C., Satoh, Y., Schmid, E., Stacke, T., Tang, Q., and Wisser, D.: Constraints and potentials of future irrigation water availability on agricultural production under climate change, Proc. Natl. Acad. Sci. USA, 111, 3239-3244, 2014.

Frieler, K., Levermann, A., Elliott, J., Heinke, J., Arneth, A., Bierkens, M. F. P., Ciais, P., Clark, D. B., Deryng, D., Döll, P., Falloon, P., Fekete, B., Folberth, C., Friend, A. D., Gellhorn, C., Gosling, S. N., Haddeland, I., Khabarov, N., Lomas, M., Masaki, Y., Nishina, K., Neumann, K., Oki, T., Pavlick, R., Ruane, A. C., Schmid, E., Schmitz, C., Stacke, T., Stehfest, E., Tang, Q., Wisser, D., Huber, V., Piontek, F., Warszawski, L., Schewe, J., Lotze-Campen, H., and Schellnhuber, H. J.: The relevance of uncertainty in future crop production for mitigation strategy planning, Earth Syst. Dynam. Discuss., 5, 1075-1099, doi:10.5194/esdd-5-1075-2014, 2014.

Friend, A. D., Lucht, W., Rademacher, T. T., Keribin, R., Betts, R., Cadule, P., Ciais, P., Clark, D. B., Dankers, R., Falloon, P. D., Ito,
A., Kahana, R., Kleidon, A., Lomas, M. R., Nishina, K., Ostberg, S., Pavlick, R., Peylin, P., Schaphoff, S., Vuichard, N., Warszawski, L., Wiltshire, A., and Woodward, F. I.: Carbon residence time dominates uncertainty in terrestrial vegetation responses to future climate and atmospheric $\mathrm{CO}_{2}$, Proc. Natl. Acad. Sci. USA, 111, 3280-3285, 2014.

Füssel, H. M., Toth, F. L., Van Minnen, J. G., and Kaspar, F.: Climate impact response functions as impact tools in the tolerable windows approach, Clim. Change, 56, 91-117, 2003.

Gerten, D., Lucht, W., Ostberg, S., Heinke, J., Kowarsch, M., Kreft, H., Kundzewicz, Z. W., Rastgooy, J., Warren, R., and Schellnhuber, H. J.: Asynchronous exposure to global warming: freshwater resources and terrestrial ecosystems, Environ. Res. Lett., 8, 034032, doi:10.1088/1748-9326/8/3/034032, 2013.

Gervois, S., Ciais, P., de Noblet-Ducoudré, N., Brisson, N., Vuichard, N., and Viovy, N.: Carbon and water balance of European croplands throughout the 20th century, Global Biogeochem. Cy., 22, GB2022, doi:10.1029/2007GB003018, 2008.

Haddeland, I., Clark, D. B., Franssen, W., Ludwig, F., Voss, F., Arnell, N. W., Bertrand, N., Best, M., Folwell, S., Gerten, D., Gomes, S., Gosling, S. N., Hagemann, S., Hanasaki, N., Harding, R., Heinke, J., Kabat, P., Koirala, S., Oki, T., Polcher, J., Stacke, T., Viterbo, P., Weedon, G. P., and Yeh, P.: Multimodel Estimate of the Global Terrestrial Water Balance: Setup and First Results, J. Hydrometeorol., 12, 869-884, 2011.

Haddeland I., Heinke, J., Biemans, H., Eisner, S., Flörke, M., Hanasaki, N., Konzmann, M., Ludwig, F., Masaki, Y., Schewe, J., Stacke, T., Tessler, Z. D., Wada, Y., and Wisser, D.: Global water resources affected by human interventions and climate change, Proc. Natl. Acad. Sci. USA, 111, 3251-3256, 2014.

Hagemann, S., Chen, C., Haerter, J. O., Heinke, J., Gerten, D., and Piani, C.: Impact of a statistical bias correction on the projected hydrological changes obtained from three GCMs and two hydrology models, J. Hydrometeorol., 12, 556-578, 2011.

Hagemann, S., Chen, C., Clark, D. B., Folwell, S., Gosling, S. N., Haddeland, I., Hanasaki, N., Heinke, J., Ludwig, F., Voss, F., and Wiltshire, A. J.: Climate change impact on available water resources obtained using multiple global climate and hydrology models, Earth Syst. Dynam., 4, 129-144, doi:10.5194/esd4-129-2013, 2013.

Hare, B.: Relationship between increases in global mean temperature and impacts on ecosystems, food production, water and socio-economic systems, in: Avoiding dangerous climate change, edited by: Schellnhuber, H. J., Cramer, W., Nakicenovic, N., Wigley, T., and Yohe, G., Cambridge Univ. Press, Cambridge, UK, 2006.

Hempel, S., Frieler, K., Warszawski, L., Schewe, J., and Piontek, F.: A trend-preserving bias correction - the ISI-MIP approach, Earth Syst. Dynam., 4, 219-236, doi:10.5194/esd-4-219-2013, 2013.

Hoff, H., Falkenmark, M., Gerten, D., Gordon, L., Karlberg, L., and Rockstrom, J.: Greening the global water system, J. Hydrol., 384, 177-186, 2010.

Howells, M., Hermann, S., Welsch, M., Bazilian, M., Segerström, R., Alfstad, T., Gielen, D., Rogner, H., Fischer, G., van Velthuizen, H., Wiberg, D., Young, C., Roehrl, A., Mueller, A., Steduto, P., and Ramma, I.: Integrated analysis of climate change, land-use, energy and water strategies, Nat. Clim. Change, 3, 621-626, 2013. 
Impacts World Conference, Visioning Document: available at: http://www.climate-impacts-2013.org/files/visioning document_impacts_world_2013.pdf (last access: 28 April 2014), 2013.

Jung, M., Reichstein, M., Ciais, P., Seneviratne, S. I., Sheffield, J., Goulden, M. L., Bonan, G., Cescatti, A., Chen, J., de Jeu, R., Dolman, A. J., Eugster, W., Gerten, D., Gianelle, D., Gobron, N., Heinke, J., Kimball, J., Law, B. E., Montagnani, L., Mu, Q., Mueller, B., Oleson, K., Papale, D., Richardson, A. D., Roupsard, O., Running, S., Tomelleri, E., Viovy, N., Weber, U., Williams, C., Wood, E., Zaehle, S., and Zhang, K.: Recent decline in the global land evapotranspiration trend due to limited moisture supply, Nature, 467, 951-954, 2010.

Kerr, R. A.: Time to Adapt to a Warming World, But Where's the Science?, Science, 334, 1052-1053, 2011.

Knopf, B., Luderer, G., Edenhofer, O.: Exploring the feasibility of low stabilization targets, WIREs Clim. Change, 2, 617-626, doi:10.1002/wcc.124, 2011.

Knutti, R.: The end of model democracy?, Clim. Change, 102, 395-404, 2010.

Knutti, R., Masson, D., and Gettelman, A.: Climate model genealogy: Generation CMIP5 and how we got there, Geophys. Res. Lett., 40, 1194-1199, 2013.

Knutti, R. and Sedláček, J.: Robustness and uncertainties in the new CMIP5 climate model projections, Nat. Clim. Change, 3, 369-373, 2013.

Kunreuther, H., Heal, G., Allen, M., Edenhofer, O., Field, C. B., and Yohe, G.: Risk management and climate change, Nat. Clim. Change, 3, 447-450, 2013.

Moss, R. H., Edmonds, J. A., Hibbard, K. A., Manning, M. R., Rose, S. K., van Vuuren, D. P., Carter, T. R., Emori, S., Kainuma, M., Kram, T., Meehl, G. A., Mitchell, J. F. B., Nakicenovic, N., Riahi, K., Smith, S. J., Stouffer, R. J., Thomson, A. M., Weyant, J. P., and Wilbanks, T. J.: The next generation of scenarios for climate change research and assessment, Nature, 463, 747-756, 2010.

Parry, M., Arnell, N., Hulme, M., Martens, P., Nicholls, R., and White, A.: The global impact of climate change: a new assessment, Global Environ. Chang., 9, S1-S2, 1999.

Parry, M. L., Canziani, O. F. Palutikof, J. P., and Co-authors: Technical Summary, in: Climate Change 2007: Impacts, Adaptation and Vulnerability, Contribution of Working Group II to the Fourth Assessment Report of the Intergovernmental Panel on Climate Change, edited by: Parry, M. L., Canziani, O. F., Palutikof, J. P., van der Linden, P. J., and Hanson, C. E., Cambridge University Press, Cambridge, UK, 23-78, 2007.

Piontek, F., Müller, C., Pugh, T. A. M., Clark, D., Deryng, D., Elliott, J., de Jesus Colón González, F., Flörke, M., Folberth, C., Franssen, W., Frieler, K., Friend, A. D., Gosling, S. N., Hemming, D., Khabarov, N., Kim, H., Lomas, M. R., Masaki, Y., Mengel, M., Morse, A., Neumann, K., Nishina, K., Ostberg, S., Pavlick, R., Ruane, A. C., Schewe, J., Schmid, E., Stacke, T., Tang, Q., Tessler, Z. D., Tompkins, A. M., Warszawski, L., Wisser, D., and Schellnhuber, H. J.: Multisectoral climate impact hotspots in a warming world, Proc. Natl. Acad. Sci. USA, 111, 3233-3238, 2014.

Prudhomme, C., Giuntoli, I., Robinson, E. L., Clark, D. B., Arnell, N. W., Dankers, R., Fekete, B.M., Franssen, W., Gerten, D., Gosling, S. N., Hagemann, S., Hannah, D. M., Kim, H., Masaki, Y., Satoh, Y., Stacke, T., Wada, Y., and Wisser, D.: Hydrological droughts in the 21st century: hotspots and uncertainties from a global multi-model ensemble experiment, Proc. Natl. Acad. Sci. USA, 111, 3262-3267, 2014.

Pindyck, R. S.: Climate change policy: What do the models tell us?, J. Econ. Lit., 51, 860-872, 2013.

Rammig, A., Jupp, T., Thonicke, K., Tietjen, B., Heinke, J., Ostberg, S., Lucht, W., Cramer, W., and Cox, P.: Estimating the risk of Amazonian forest dieback, New Phytol., 187, 694-706, 2010.

Rötter, R. P., Carter, T. R., Olesen, J. E., and Porter, J. R.: Crop-climate models need an overhaul, Nat. Clim. Change, 1, 175-177, 2011.

Rogelj, J., Hare, W., Lowe, J., van Vuuren, D. P., Riahi, K., Matthews, B., Hanaoka, T., Jiang, K., and Meinshausen, M.: Emission pathways consistent with a 2 degrees $\mathrm{C}$ global temperature limit, Nat. Clim. Change, 1, 413-418, 2011.

Rosenzweig, C., Jones, J. W., Hatfield, J. L., Ruane, A. C., Boote, K. J., Thorburne, P., Antle, J. M., Nelson, G. C., Porter, C., Janssen, S., Asseng, S., Basso, B., Ewert, F., Wallach, D., Baigorria, G., and Winter, J. M.: The Agricultural Model Intercomparison and Improvement Project (AgMIP): Protocols and pilot studies, Agr. Forest Meteorol., 170, 166-182, 2013.

Rosenzweig, C. and Wilbanks, T. J.: The state of climate change vulnerability, impacts, and adaptation research: strengthening knowledge base and community, Clim. Change, 100, 103-106, 2010.

Rosenzweig, C., Elliott, J., Deryng, D., Ruane, A. C., Müller, C., Arneth, A., Boote, K. J., Folberth, C., Glotter, M., Khabarov, N., Neumann, K., Piontek, F., Pugh, T. A. M., Schmid, E., Stehfest, E., Yang, H., and Jones, J. W.: Assessing agricultural risks of climate change in the 21 st century in a global gridded crop model intercomparison, Proc. Natl. Acad. Sci. USA, 111, 3268-3273, 2014.

Ruti, P. M., Williams, J. E., Hourdin, F., Guichard, F., Boone, A., van Velthoven, P., Favot, F., Musat, I., Rummukainen, M., Dominguez, M., Gaertner, M. A., Lafore, J. P., Losada, T., Rodriguez de Fonseca, M. B., Polcher, J., Giorgi, F., Xue, Y., Bouarar, I., Law, K., Josse, B., Barret, B., Yang, X., Mari, C., and Traore, A. K.: The West African climate system: a review of the AMMA model inter-comparison initiatives, Atmos. Sci. Lett., 12, 116-122, 2011.

Sanderson, B. M. and Knutti, R.: On the interpretation of constrained climate model ensembles, Geophys. Res. Lett., 39, L16708, doi:10.1029/2012GL052665, 2012.

Schellnhuber, H. J., Frieler, K. and Kabat, P.: The Elephant, the Blind, and the ISI-MIP, Proc. Natl. Acad. Sci. USA, 111, 3225-3227, 2014.

Schewe, J., Heinke, J., Gerten, D., Haddeland, I., Arnell, N. W., Clark, D. B., Dankers, R., Eisner, S., Fekete, B., Colón-González, F. J., Gosling, S. N., Kim, H., Liu, X., Masaki, Y., Portmann, F. T., Satoh, Y., Stacke, T., Tang, Q., Wada, Y., Wisser, D., Albrecht, T., Frieler, K., Piontek, F., Warszawski, L., and Kabat, P.: Multimodel assessment of water scarcity under climate change, Proc. Natl. Acad. Sci. USA, 111, 3245-3250, 2014.

Schneider, S. H. and Mastrandrea, M. D.: Probabilistic assessment of "dangerous" climate change and emissions pathways, Proc. Natl. Acad. Sci. USA, 102, 15728-15735, 2005.

Sitch, S., Huntingford, C., Gedney, N., Levy, P. E., Lomas, M., Piao, S. L., Betts, R., Ciais, P., Cox, P., Friedlingstein, P., Jones, C. D., Prentice, I. C., and Woodward, F. I.: Evaluation of the ter- 
restrial carbon cycle, future plant geography and climate-carbon cycle feedbacks using five Dynamic Global Vegetation Models (DGVMs), Global Change. Biol., 14, 2015-2039, 2008.

Smith, J. B., Schellnhuber, H.-J., Monirul Qader Mirza, M., and Co-Authors: Vulnerability to Climate Change and Reasons for Concern: A Synthesis, in: Climate Change 2001: Impacts, Adaptation, and Vulnerability, edited by: McCarthy, J. J., Canziani, O. F., Leary, N. A., Dokken, D. J., and White, K. S., Cambridge Univ. Press, UK, 2001.

Smith, J. B., Schneider, S. H., Oppenheimer, M., Yohe, G. W., Hare, W., Mastrandrea, M. D., Patwardhan, A., Burton, I., CorfeeMorlot, J., Magadza, C. H. D., Fuessel, H. M., Pittock, A. B., Rahman, A., Suarez, A., and van Ypersele, J. P.: Assessing dangerous climate change through an update of the Intergovernmental Panel on Climate Change (IPCC) "reasons for concern", Proc. Natl. Acad. Sci. USA, 106, 4133-4137, 2009.

Stern, N.: The structure of economic modeling of the potential impacts of climate change: Grafting gross underestimation of risk onto already narrow science models, J. Econ. Lit., 51, 838-859, 2013.

Tavoni, M. and Tol, R. S. J.: Counting only the hits? The risk of underestimating the costs of stringent climate policy, Clim. Change, 100, 769-778, 2010.

Taylor, K. E., Stouffer, R. J., and Meehl, G. A.: A summary of the CMIP5 experiment design, PCMDI Rep., 33, 2011.

Tebaldi, C. and Knutti, R.: The use of the multi-model ensemble in probabilistic climate projections, Philos. T. R. Soc. A, 365, 2053-2075, 2007.

UNFCCC 2010: The Cancun Agreements, available at: http://cancun.unfccc.int/cancun-agreements/ significance-of-the-key-agreements-reached-at-cancun/, last access: 31 March 2014.

van Vuuren, D. P., Riahi, K., Moss, R., Edmonds, J., Thomson, A., Nakicenovic, N., Kram, T., Berkhout, F., Swart, R., Janetos, A., Rose, S. K.. and Arnell, N.: A proposal for a new scenario framework to support research and assessment in different Clim. Res. communities, Global Environ. Chang., 22, 21-35, 2012.

Vetter, M., Churkina, G., Jung, M., Reichstein, M., Zaehle, S., Bondeau, A., Chen, Y., Ciais, P., Feser, F., Freibauer, A., Geyer, R., Jones, C., Papale, D., Tenhunen, J., Tomelleri, E., Trusilova, K., Viovy, N., and Heimann, M.: Analyzing the causes and spatial pattern of the European 2003 carbon flux anomaly using seven models, Biogeosciences, 5, 561-583, doi:10.5194/bg-5561-2008, 2008.

Wada, Y., Wisser, D., Eisner, S., Floerke, M., Gerten, D., Haddeland, I., Hanasaki, N., Masaki, Y., Portmann, F. T., Stacke, T., Tessler, Z., and Schewe, J.: Multimodel projections and uncertainties of irrigation water demand under climate change, Geophys. Res. Lett., 40, 4626-4632, 2013.
Waldhoff, S., Martinich, J., Sarofim, M., DeAngelo, B., McFarland, J., Jantarasami, L., Shouse, K., Crimmins, A., and Li, J.: Overview of the Special Issue: a multi-model framework to achieve consistent evaluation of climate change impacts in the United States, Clim. Chang., doi:10.1007/s10584-014-1206-0, online first, 2014.

Warren, R.: Impacts of global climate change at different annual mean global temperature increases, in: Avoiding dangerous climate change, edited by: Schellnhuber, H. J., Cramer, W., Nakicenovic, N., Wigley, T., and Yohe, G., Cambridge Univ. Press, Cambridge, UK, 2006.

Warren, R.: The role of interactions in a world implementing adaptation and mitigation solutions to climate change, Philos. T. R. Soc. A, 369, 217-241, 2011.

Warszawski, L., Friend, A., Ostberg, S., Frieler, K., Lucht, W., Schaphoff, S., Beerling, D., Cadule, P., Ciais, P., Clark, D. B., Kahana, R., Ito, A., Keribin, R., Kleidon, A., Lomas, M., Nishina, K., Pavlick, R., Rademacher, T. T., Buechner, M., Piontek, F., Schewe, J., Serdeczny, O., and Schellnhuber, H. J.: A multi-model analysis of risk of ecosystem shifts under climate change, Environ. Res. Lett., 8, 044018, doi:10.1088/17489326/8/4/044018, 2013.

Warszawski, L., Frieler, K., Huber, V., Piontek, F., Serdeczny, O., and Schewe, J.: The Inter-Sectoral Impact Model Intercomparison Project (ISI-MIP): Project framework, Proc. Natl. Acad. Sci. USA, 111, 3228-3232, 2014.

Wood, E. F., Roundy, J. K., Troy, T. J., van Beek, R., Bierkens, M., Blyth, E., de Roo, A., Doell, P., Ek, M., Famiglietti, J., Gochis, D., van de Giesen, N., Houser, P., Jaffe, P., Kollet, S., Lehner, B., Lettenmaier, D. P., Peters-Lidard, C., Sivapalan, M., Sheffield, J., Wade, A., and Whitehead, P.: Hyper-Resolution Global Land Surface Modeling: Meeting a Grand Challenge for Monitoring Earth's Terrestrial Water, Water Resour. Res., 47, W05301, doi:10.1029/2010WR010090, 2011.

Xia, Y., Mitchell, K., Ek, M., Sheffield, J., Cosgrove, B., Wood, E., Luo, L., Alonge, C., Wei, H., Meng, J., Livneh, B., Lettenmaier, D., Koren, V., Duan, Q., Mo, K., Fan, Y., and Mocko, D.: Continental-scale water and energy flux analysis and validation for the North American Land Data Assimilation System project phase 2 (NLDAS-2): 1. Intercomparison and application of model products, J. Geophys. Res.-Atmos., 117, D03109, doi:10.1029/2011JD016048, 2012. 